\title{
Transmedia Literacy: Analyzing the Impact of The X-Files Transmedia Strategies
}

\section{Daiana Sigiliano ${ }^{1}$ Gabriela Borges ${ }^{2}$}

Recibido: 02/02/2018

Aprobado por pares: 18/04/2018
Enviado a pares: 11/02/2018

Aceptado: 31/05/2018

DOI: 10.5294/pacla.2019.22.2.3

To reference this article / para citar este artículo / para citar este artigo

Sigiliano, D. \& Borges, G. (2019). Transmedia literacy: Analyzing the impact of The X-Files transmedia strategies. Palabra Clave, 22(2), e2223. DOI: 10.5294/pacla.2019.22.2.3

\section{Abstract}

Based on the theoretical framework that transmedia literacy encourages public participation and critical understanding of fictional universes, for example, when navigating different platforms, correlating to the transmedia strategies with the main media, the interacting agent performs an attentive or polysemic reading of the fictional universe; this paper aims to analyze a number of Twitter posts made by interacting audience members of The $X$-Files during the launch of transmedia actions regarding the show's $10^{\text {th }}$ season. In this context, the tweets will help us to reflect on the concept of transmedia literacy and how it stimulates the public's multilateralism. The conclusion is that transmedia action encourages learning through collaboration and critical understanding.

\section{Keywords (Source: Unesco Thesaurus)}

Transmedia literacy; television; The X-Files; Twitter; interacting audience.

1 orcid.org/0000-0002-5163-9926. Universidade Federal de Juiz de Fora, Brazil.

2 orcid.org/0000-0002-0612-9732. Universidade Federal de Juiz de Fora, Brazil. gabriela.borges@uff.edu.br 


\section{Alfabetismo transmedia: un análisis de la repercusión de las estrategias transmedia de The $X$-Files}

\section{Resumen}

Con base en la teoría de que el alfabetismo transmedia fomenta la participación y la comprensión crítica del público de los universos ficticios, por ejemplo, al navegar por diferentes plataformas, correlacionando las estrategias transmedia con los principales medios, el agente que interactúa realiza una lectura atenta o polisémica del universo ficticio; este artículo tiene como objetivo analizar algunas publicaciones en Twitter de los telespectadores interactivos de Los expedientes secretos $X$ durante el lanzamiento de las acciones transmedia relacionadas con la décima temporada de la serie. En este contexto, los tuits nos ayudan a reflexionar sobre el concepto de alfabetismo transmedia y cómo este estimula el multilateralismo público. Se concluye que la acción transmedia impulsa el aprendizaje por medio de la colaboración y el entendimiento crítico.

\section{Palabras clave (Fuente: tesauro de la Unesco)}

Alfabetismo transmedia; televisión; Los expedientes secretos $X$; Twitter; audiencia interactiva. 


\section{Transmedia literacy. uma análise do impacto das estratégias transmídiado Arquivo $X$}

\section{Resumo}

A partir da teoria de que a transmedia literacy estimula a participação e a compreensão crítica do público dos universos fictícios, por exemplo, ao navegar em diferentes plataformas, correlacionando as estratégias transmídia com as principais mídias, o agente que interage realiza uma leitura atenta ou polissêmica do universo ficcional; este artigo tem como objetivo analisar algumas publicações em Twitter do público interativo do show Arquivo $X$ durante o lançamento das ações transmídia relacionadas com a décima temporada da série. Neste contexto, os tuítes nos ajudam a refletir sobre $o$ conceito de transmedia literacy e como ele estimula o multilateralismo público. Conclui-se que a ação promove a aprendizagem através da colaboração e do entendimento crítico.

\section{Palavras-chave (Fonte: tesauro da Unesco)}

Cinema; técnica cinematográfica; corpo; atenção tempo; modernidade. 


\section{Introduction}

The phenomena permeating contemporary television show that the current media landscape is guided by the hybridization of communication outlets and that new means of creating, producing and distributing televised content emerge from this interpretation of media languages (Lotz, 2007). In this context, fictional universes of Post-Network Television shows are so complex that they cannot be contained within a single outlet. That is, to support the density of characters and narrative threads, stories go beyond television, expanding into multiple platforms. As stated by Johnson (2012), "just like shows have gotten more complex, the resources to understand this complexity have also multiplied” (p. 92). Besides being crucial in supporting the dense plots of contemporary TV shows, transmedia allows the audience to see different perspectives of the same attraction, going beyond the single perspective offered by television.

Coined ${ }^{3}$ by Jenkins (2006), the concept of transmedia narrative emerges from the fluidity of fictional universes in the current media convergence climate. According to the author, a "transmedia story is developed through multiple media platforms, with each new text contributing to the whole in a unique and valuable way" (Jenkins, 2006, p. 138). This model of industry production is composed by the reference content, i.e., the core media, and by transmedia strategies created from it (Fechine, 2016, p. 5).

However, it's important to highlight that the phenomenon of stories sliding through different outlets predates the convergence environment (Figueredo, 2010; Mittell, 2015; Freeman, 2017). Novels such as The Wizard of Oz (1900), Don Quijote de la Mancha (1605), Frankenstein, or the Modern Prometheus (1816) and Alice's Adventures in Wonderland (1865) had their stories expanded into illustration, theater plays, songs, etc. As explained by Mittell (2015):

Any thoughtful study of contemporary transmedia must acknowledge that transmedia is not a new phenomenon but predates the digital

3 Jenkins's (2006) discussions show some similarity with Marsha Kinder's (1991) studies on transmedia intertextuality. In her book, Playing with Power in Movies, Television, and Video Games: From Muppet Babies to Teenage Mutant Ninja Turtles, published in 1991, Kinder introduces the concept to reflect on systems of over-entertainment, which emerge from combining different platforms and narratives. This process, according to the author, would turn consumers into avid players. 
age. Even if the term is new, the strategy of adapting and expanding a narrative into other media is as old as media themselves - think of paintings dramatizing biblical or Sherlock Holmes whose narrative scope transcends any single medium. (p. 292)

This narrative sliding mentioned by Mittell (2015) is not restricted to literature; the same logic can be applied to American television shows. Broadcast by NBC in the 1950s, Dragnet (1951-1959) had its story expanded into film, radio, and even in a board game, with each ramification exploring a different perspective from the main plot. The narrative extensions of Twin Peaks (1990-1991, ABC) also predate media convergence. Published during the break between the first and second seasons, the book The Secret Diary of Laura Palmer was written by David Lynch, one of the show's creators, with his daughter, Jennifer Lynch. The book presented important information regarding Laura Palmer's (Sheryl Lee) past, which had not been developed in television. Due to the book's success, two other volumes were published as the show's second season was aired: Twin Peaks: An Access Guide to the Town, a tourist guide of the city where the show was set, and "Diane...": The Twin Peaks Tapes of Agent Cooper, which gathered the transcription of recordings sent by Agent Dale Cooper (Kyle MacLachlan) to the mysterious character, Diane. A year after the series finale, a feature film was produced: Twin Peaks: Fire Walk with Me (David Lynch, 1992). The story happens in the show's fiction universe, but focuses on the investigations of the murder of Teresa Banks (Pamela Gidley).

According to Johnson (2012) and Mittell (2015), these narrative expansions, which have always permeated stories, gain new configurations in the convergence ecosystem. That is, this climate allows for the creation of fictional universes that slide through various outlets - webisodes, blogs, computer games, alternate reality games, second screen apps, books, comics, etc. - and encourage audience participation. In this context, transmedia reconfigures old practices, adopting new platforms and new engagement methods for the interacting audience ${ }^{4}$ (Johnson, 2012; Mittell, 2015).

4 The concept of interacting audience/viewer is used in this paper to describe the audience that interacts (promotes, retweets, creates content, responds to polls, etc.) with the fictional universe of TV series (Sigiliano \& Borges, 2016). 
According to Mittell (2015, p. 293-295), transmedia strategies in television are used with the following goals: promoting, presenting and marketing a piece of content; expanding and detailing the fictional universe presented in the mother ship; engaging and rewarding the interacting audience and sustaining their interest during breaks. Dawson's Creek (19982003, The WB) was one of the first American TV shows to use transmedia strategies to enrich its fictional universe and engage with the audience (Evans, 2011; Jenkins, 2006). Developed by Chris Pike, Dawson's Desktop represented Dawson Leery's (James Van Der Beek) computer desktop. In the website one could read the character's e-mails, diary and school work. According to Jenkins (2006), "the desktop's artifice allowed the producers to bring the audience into the characters' heads, seeing new dimensions to their social interactions" (p. 165). Updated daily, Dawson's Desktop reached 25 million weekly visits (Evans, 2011, p. 22). The website's contents extended the show's narrative arcs, offering the audience exclusive plot details.

Nowadays, every American TV channel, whether network or broadcast, has at least one show featuring transmedia action. As a matter that shall be further discussed, the strategies explore specific story points that were not shown in depth in the TV episodes.

\section{Transmedia in Fan Culture}

According to Jenkins, Green, and Ford (2012) and Mittell (2015), transmedia narratives encourage audience participation. In this sense, spectators interact with actions created by networks and correlate scattered pieces of content with the central plot.

Transmedia strategies assume that the gradual dispersion of material can sustain various kinds of audience conversation, rewarding and building particularly strong connections with the more intense fans of a media property, while inspiring others to be even more active in their search and sharing of new information. (Jenkins et al., 2012, p. 206)

This audience participation in transmedia actions becomes even clearer and more active when we observe fans of serialized fictional narratives. Mittell (2016) draws attention to forensic fandom ${ }^{5}$ communities;

5 Fandom (a shortened form of "fan kingdom") refers to a group of fans. 
according to the author, fans gather in social media and specialized forums to decode and meticulously analyze a show's narrative expansion. These resources used by fans in understanding and close reading transmedia actions dialogue with the concept of collective intelligence as discussed by Lévy (2014). The author states that collective intelligence "is a kind of intelligence which is distributed everywhere, unceasingly valued, coordinated in real time, resulting in an effective mobilization of skills" (Lévy, 2014, p. 29). Thus, "no one knows everything, everyone knows something, all knowledge is in humanity" (Lévy, 2014, p. 29). Therefore, intelligence is based on "people's mutual recognition, instead of the cult of fetishized or hypostatized communities" (Lévy, 2014, p. 29). The central points of these collaborative spaces are its members' mutual knowledge and interest, and they actively communicate in spite of limits, geographical borders or institutional affiliation.

According to Lévy (2014), in collective intelligence the media subject's individual expertise becomes subordinated to common and collective goals. The author states that this point can be observed "in virtual communities capacity for leveraging their members knowledge and specialization, usually through collaboration and large scale discussion" (Lévy, 2014, p. 30). In this sense, each media subject contributes with their specific skills in order to build a collective body of knowledge. Twin Peaks was one of the first television shows to get its own online fan community ${ }^{6}$. Williams (2005) and Jenkins (2006), for their part, the forum was created weeks after the airing of the season premiere and soon became one of the biggest and most active discussion lists at the time, with twenty-five thousand subscribed users. As described by the author,

Fans worked together to create spreadsheets and charts to track the show's events or to compile important quotes; they shared what they could find about the show in local newspapers; they used the internet to find videotapes, if they missed it; they investigated the complex grid of references to other films, shows, songs, novels and popular texts. (Jenkins, 2006, p. 62)

6 Available at alt.tv.twinpeaks. 
Twin Peaks, from its central hook to the character profiles, inspired fans to work together to fill the gaps purposely left by Mark Frost and David Lynch. However, the community's capacity for organization and teamwork brought further requirements to the show. Each scene shown on television was dissected, raising theories that went beyond what had been created by the screenwriters.

Nowadays, with the popularization of social media and the quick propagation of content, fans have the opportunity to react to show's events in real time (Pearson, 2010).For example, Twitter profile @WestworldBrazil, which analyzes the HBO show Westworld (2016-current) along with other fans. Starting with information shared by the American cable network, $\mathrm{HBO}$, fans discuss possible answers for the puzzles left by the show. The same thing happens with stories such as Game of Thrones (HBO, 2011-present) and Grey's Anatomy (2005-present), among others.

\section{Transmedia Literacy: Critical Understanding of Fictional Universes}

According to Jost (2011), the convergence environment allows for creating content that depends, at least partially, on audience participation. The author's point can be seen in transmedia narratives, actions in which the interacting audience member has to access different platforms and narrative contexts and correlate them to the mother ship. For Ciastellardi and Di Rosario (2015), Jenkins (2013), and Scolari (2016), this encouragement of participation and critical understanding, in which the audience has to explore different languages and connect them to a specific context, is the main point of transmedia literacy.

However, before discussing the concept proposed by the authors, it is important to understand the definition of media literacy. Considering it is constantly adapting to communication transformations, media literacy has multiple definitions (Borges, Brandão, Sigiliano, Vieira, \& Fernandes, 2017; Borges \& Sigiliano, 2016; Potter, 2010; Rosenbaum, Beentjes, \& Konig, 2016; Scolari, 2016). According to Potter (2010), despite this plurality, discussions around the theme usually focus on the combination of 
knowledge and political, social and cultural practices that allow citizens to think critically about media outlets. In this paper, we will adopt Livingstone's (2004) definition: According to the author, media literacy refers to the ability to access, analyze, evaluate and create messages through various different contexts.

In this sense, transmedia literacy is an unfolding of media literacy. According to Scolari $(2016$, p. 8), the concept covers a set of abilities, practices, values and learning and exchange strategies developed and applied in the context of the new collaborative culture. Therefore, transmedia literacy promotes audience access, participation, analysis, content production and critical understanding (Evans, 2011; Jenkins, 2013). Navigating through various platforms, finding correlations between transmedia strategies and the core media, the media subject performs a close critical reading of the texts. Borges et al. (2017) highlight that the networks' engagement actions also encourage creative production from interacting audience. According to the authors, by systematically analyzing the story, the audience establishes new connections between narrative arcs, deepening and re-signifying the fictional universe.

Airing on American cable network, HBO, Westworld had its complex fictional universe expanded in various platforms. Launched before the show's second season premiere, website Delos Incorporated integrated one of the transmedia actions created by the network to promote the series. The link, which was shared on the show's Twitter profile, directed the interacting viewer towards the website of fictional company Delos. The content reinforced the hypothesis raised by the audience regarding the possibility of other theme parks in Westworld, beyond what was shown ${ }^{7}$ in the episodes. On the website, one could see pictures of six parks, but only three images were available: one of the Old West park, which was explored in the first season, and two of the Shogunworld and Tha Raj parks, respectively.

The action established a connection not only to interacting viewers' speculations, but also to a scene in the season finale, titled The Bicameral Mind.

7 During the first season, only the Old West park was explored by screenwriters. 
In the scene, we see Maeve (Thandie Newton) running through the laboratory's halls and finding various hosts ${ }^{8}$ dressed as samurais. After the scene aired, the audience commented on social media that they were androids from another theme park on Westworld. The information was confirmed months later during the transmedia action, when the Delos Incorporated website showed a picture of the new park and revealed the place's name and details. The website also indicated the existence of another park, Tha Raj, which, according to the description, is set in Colonial India. Therefore, the Westworld transmedia action encouraged viewers to connect content from three forms of media (television, Twitter, and the website) to the narrative arcs in the fictional universe. HBO's strategy also required the audience's close reading, since they needed to meticulously analyze the visual composition of scenes in search of answers to the informational gaps purposely left by screenwriters. As mentioned by Dinehart (2008, n.p.), "transmedia practices promote multiple literacy, stimulating the capacity to interpret broadly the discourses from different channels and languages" (our translation).

According to Jenkins (2013), Scolari (2016), and Borges et al. (2017), transmedia literacy includes multilaterality, i.e., the capacity to interpret messages in various contexts, as well as audience participation. In this sense, interacting viewers analyze actions in a collaborative manner, in social media and specialized forums, and create new content based on the expansions of fictional universes. Released during the hiatus between the first and second seasons of Mr. Robot (USA Network, 2015-present), the video game Robot:1.51exfiltratiOn ${ }^{9}$ (Universal Cable Productions LLC, 2016) had the goal of keeping the interest of interacting viewers while new episodes weren't airing and to expand the show's narrative. As explained in USA Network's website, "Our game extends the narrative of the series, allowing players to become personally involved with other hackers and fsociety characters" (Usa Network, 2016, n.p.).

In the game, available for Android and iOS, the player had to hack Evil Corp. In order to do so, they needed to exchange messages with fic-

8 The name given to the show's androids.

9 Available at https://apple.co/2J6WBhB. 
tional characters from the USA show and solve riddles and puzzles proposed by Robot:1.51 exfiltration. However, even though it had a simple and intuitive gameplay, simulating a smartphone's interface, the Mr. Robot video game was as complex as the show. After the action's release, fans began to share tips and tutorials on Twitter and Reddit regarding the levels of Robot:1.51exfiltration. The show's expansion was also re-signified by the audience on YouTube; the videos, each of which was around 3 minutes long, combined screencaps from the game and scenes from the show. The transmedia action was not only discussed in a collaborative manner by fans, but also remixed, gaining new meaning.

Thus, transmedia literacy encourages the audience's access, participation, analysis, and critical understanding. When navigating through various platforms, connecting transmedia actions to the main plot, the interacting viewer explores different interpretative layers and produces new meaning from the story.

According to Scolari (2016), because it is a recent concept, transmedia literacy has not yet been thoroughly researched; however, reflections on the theme lead to new discussions regarding contemporary narratives in media convergence. Considering this context, this paper intends to analyze Twitter posts made by interacting audience members of The X-Files during the release of the show's transmedia actions. The tweets will help us to reflect on the relevance of transmedia literacy as well as on how those actions encourage audience multilateralism, critical thinking and creative production.

\section{Transmedia in The Return of The X-Files}

Created by Chris Carter, The X-Files stars David Duchovny and Gillian Anderson as FBI agents Fox Mulder (Duchovny) and Dana Scully (Anderson). The characters investigate unsolved cases involving paranormal and/ or unexplained elements, known as $\mathrm{x}$-files. However, as the investigations progress, Mulder and Scully find a conspiracy network involving the United States government. The show aired on American television from 1993 to 2002, with nine seasons and 201 episodes in total. 
Thirteen years after the series finale was aired, during an annual Fox programming convention, held in March 2015, the network announced the return of The X-Files. Fox's engagement actions for the show's new season included additional content on YouTube, special websites, social media posts and transmedia strategies (Sigliano \& Borges, 2017).

Before we delve deeper into the transmedia actions executed during the new season of The X-Files, it's worth noting that, since its television debut, the show's fictional universe was expanded in various platforms. According to Reeves, Rodgers, and Epstein (1996), The X-Files' narrative arcs were extended and re-signified through books, comics, video games, spin-offs, and movies. As pointed out by the authors, each one of these developments contributes in its own way to the audience's understanding and immersion.

Through the show's nine seasons, 37 literary adaptations of episodes aired on Fox were published, detailing the plots and exploring new aspects of the story. In addition to the books, annual guides were also published, featuring information about each season (actor bios, technical specs, summaries, fun facts, etc.), as well as special editions focused on specific areas of the show, such as science, art direction, and even the locations where it was shot.

Created under the supervision of The X-Files screenwriters, the comic books offered brand new cases for Mulder and Scully. Even though some successful episodes were transposed to comics-for example, Space, Fire and Beyond the Sea-, the main goal of the project was the possibility to explore aspects of the fiction universe that didn't fit the television format (Dowd, Niederman, Fry, \& Steiff, 2013).

Fox also created two video games based on the show: The X-Files: Unrestricted Access (1997) and The X-Files: Game (1998). Even though both of them had new plots, their visuals and gameplay were quite different.

To expand The X-Files franchise and capitalize on the show's popularity, the network created in 2001 the spin-off show The Lone Gunmen (2001). It starred John Fitzgerald Byers (Bruce Harwood), Melvin Frohike (Tom 
Braidwood) and Richard Langly (Dean Haglund) and dove deeper into a secondary arc from the main show. The fictional universe was also expanded into two feature films. The X-Files: Fight the Future (1998) premiered in the hiatus between the show's fifth and sixth seasons and faced the challenge of appealing to an outsider audience, that didn't watch the show, as well as offering the fans some answers. According to Scoladari and Felder (2000), due to frequent complaints about informational gaps left by screenwriters, the showrunner, Chris Carter, decided to use the movie to answer some questions about the show's mythology, such as, for example, Scully's disease and the black oil.

The X-Files: I Want to Believe (2008) premiered after the show had finished. Even though it brought the FBI agents back six years after the series finale, the movie distanced itself from the show's mythology and was heavily criticized by part of the audience.

As pointed out by Reeves, Rodgers and Epstein (1996) and Mclean (1998), the expansions of the fictional universe of The X-Files drew the attention of fans, who explored each transmedia action in search of new perspectives on the show. Identified as X-Philes, or just Philes, The X-Files fans gathered on the internet to exchange information about the show. The authors explain that, in collaborative spaces, the fans analyzed episode scenes, created games based on recurrent elements in the show (flashlights, extra-terrestrial, character catchphrases, etc.), created customized material based on the show (mugs, t-shirts, wallpapers, etc.), organized season guides with details about the cast, the crew and episode summaries and ratings, drew mind maps of the fictional universe and the character relationships, shared information about the actors' careers, posted content shared by the press and negotiated for official merchandise.

Even though there were innumerable websites dedicated to the fictional universe of The X-Files as the nine seasons aired, discussions about the show were concentrated in two spaces: the mailing list $\mathrm{x}$-files@chaos. taylored.edu and the forum alt.tv.x-files (Clerc, 1996). According to Clerc (1996, p. 43), the mailing list had around 1.5k members and demanded dedication, since updates were incessant. The author states that, even 
though it was broad, the list had a personal aspect, since all subscribers knew each other.

However, the biggest hub of discussion and analysis was the forum alt.tv.x-files. As pointed out by McLean (1998), the website celebrated and validated fan knowledge. The alt.tv server was popularized in the scope of television with Twin Peaks. Created weeks after the season premiere, atl.tv.twinpeaks quickly became one of the biggest and most active discussion lists at the time, with twenty-five thousand subscribers and around one hundred daily posts (Jenkins, 2006).

Unlike the mailing list $\mathrm{x}$-files@chaos.taylored.edu, one didn't need to register to access alt.tv.x-files posts; that was only required if the user wanted to post. One of the strongest points of the forum were spectator analysis, involving multiple interpretation levels (Clerc, 1996). After the show aired on television, the audience dissected the story frame by frame. Discussions included the cast's performance, the quality of art direction in characterizations and, in particular, the gaps in mythology and the intertextuality present in independent arcs.

The show's tenth season, which aired in the United States from January to February 2016, had six episodes (My Struggle, Founder's Mutation, Mulder and Scully Meet the Were-Monster, Home Again, Babylon, and My Struggle II). Released in November 2015, transmedia strategy Find The X offered exclusive episode content. In order to gain access to the footage, the audience needed to decipher clues shared by the show's official Twitter profile, @thexfiles. The page posted information regarding one of the show's characters and the answer to the riddle led to the actor who played that character, where the image of an $X$ could be seen. In order to release the content, the interacting viewer had to retweet (RT) the post until it reached the number of retweets determined by @thexfiles.

An example was the action released in the show's Twitter page on November 19, 2015 (Figure 1). In the afternoon, they posted the following information: "Want to play \#FindTheX? We've created an online scavenger hunt with a Flock to Unlock. Get ready for our next tweet...\#TheXFiles" 
(The X-Files, 2015a) and "On \#TheXFiles she is sometimes called Starbuck...she has hidden the X. Find it \& RT w/ \#FindTheX. 10K tweets unlocks a glimpse of the truth!" (The X-Files, 2015b).

\section{Figure 1. Posts made by the show's official Twitter page during \#FindTheX}
(x)
The X-Files
@thexfiles
(x) The X-Files
Want to play \#FindTheX? We've created an online scavenger hunt with a Flock to Unlock. Get ready for our next tweet...\#TheXFiles
(3) Traduzido do inglês 19/11/15 14:57
On \#TheXFiles she's sometimes called Starbuck...she has hidden the X. Find it \& RT W/ \#FindTheX. 10k tweets unlocks a glimpse of the truth!
(3) Traduzido do inglês
$19 / 11 / 1514: 59$

Source: The X-Files verified Twitter account.

The answer to the clue given by @thexfiles was the profile of actress Gillian Anderson, who plays Scully. As a child, the FBI agent used to be called Starbuck by her father, William Scully (Don S. Davis) ${ }^{10}$. When the protagonist's personal page on the microblogging website was accessed, one could read the following tweet: "You found the X!!! $10 \mathrm{k}$ RTS unlocks a glimpse of the truth! @thexfiles \#FindTheX” (The X-Files, 2015b). After reaching ten thousand retweets, the show's official page shared a link for a Tumblr page and a password (XPhiles). After following the link to the blogging platform and typing in the password, it was possible to watch exclusive The X-Files content (Figure 2).

However, engagement continued even after the videos were released: The audience shared frames of the scenes in their Twitter profiles and discussed the developments of the show's narrative arcs. The Find the $\mathrm{X}$ transmedia action had three editions, with actors Gillian Anderson, Mitch Pileggi, and David Duchovny ${ }^{11}$ and generated around thirty-five thousand RTs in total.

10 A reference to Herman Melville's book, Moby-Dick (1851).

11 Available at: https://twitter.com/davidduchovny. 


\section{Figure 2. Posts made by Gillian Anderson and The X-Files verified Twitter accounts after ten thousand retweets*}

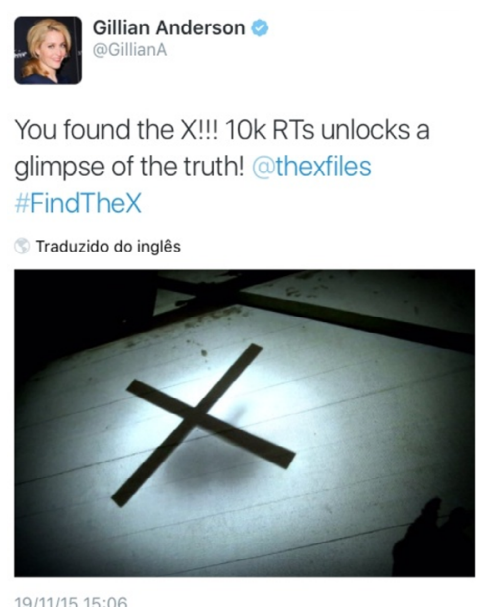

(ג) The X-Files

(1)

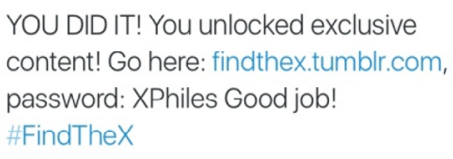

(3) Traduzido do inglês

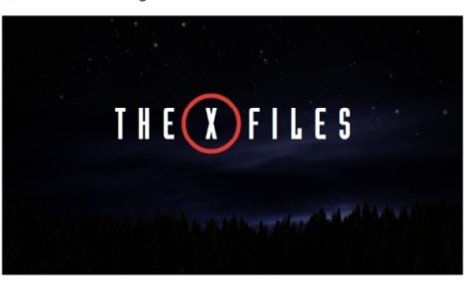

$19 / 11 / 1523: 50$

Source: Twitter.

*Note: The personal profile of actress Gillian Anderson (@GillianA) takes part in the transmedia action and, after reaching ten thousand tweets, the official The X-Files page (@thexfiles) shares exclusive scenes of season 10 episodes.

\section{Find The $X$ and Transmedia Literacy}

In order to analyze the content shared by the audience during Find The $\mathrm{X}$, we monitored tweets containing the transmedia action's official indexing, the hashtag \#FindTheX. As adopted in previous research, this methodological approach to monitoring, collecting and mining tweets extracts data from Twitter's Application Programming Interface (API) (Sigiliano \& Borges, 2017). Starting from this database, posts containing the \#FindTheX hashtag were projected onto TweetDeck and captured by the Snagit software. The analysis corpus covered every edition of Find The X, totaling 6,291 tweets. Afterwards, we analyzed each publication individually, with the intent of reflecting on how actions promote multilateralism, critical understanding and creative production.

Before digging deeper into the content shared by the interacting audience on Twitter during the transmedia action Find The $\mathrm{X}$, it is important to remember that the show's strategy dialogues with transmedia literacy. As 
pointed out by Herr-Stephenson, Alper, and Reilly (2013), transmedia not only encourages the fandom to interpret media in various linguistic contexts, but also to connect and correlate scattered information. The types of reading mentioned by the authors can be seen in Find The X. The action combined four platforms: Twitter, Tumblr, YouTube, and television. This means that the fan had to access the microblogging platform, go to at least two profiles (the show's and the participating actor's), click on the link posted by @thexfiles, go to Tumblr and type the password XPhiles, watch the YouTube video and, finally, connect the images with narrative arcs of The $X$-Files fictional universe. The transmedia action also depended directly on the interacting audience to decipher clues, reach the number of retweets determined by the Twitter page and, finally, fill the plot's narrative gaps connecting the YouTube video to Chris Carter's show. In this sense, as pointed out by Jenkins (2013, n.p.), in transmedia literacy, "the scattered fragments of a transmedia story are like pieces of a puzzle; they encourage curiosity, exploration, experimentation and problem solving".

Transmedia literacy also encourages the audience's creative production. After exclusive content of The X-Files's tenth season was shared, the fans published on Twitter their impressions of scenes shared by Find The $\mathrm{X}$. The tweets drew attention to the image's narrative developments and tried to connect the sequences with plots and subplots left open-ended in previous seasons. Before analyzing the scenes, the interacting fandom systematized the content. In this sense, a video that averaged 30 seconds in length was broken down into hundreds of frames. Afterwards, each screen capture was carefully examined by the fans. For example, images showing the silhouette of a smoking man and Scully wearing black clothes. The fandom came to the conclusion that, even though The X-Files's ninth season indicated that the antagonist, Cancer Man (William B. Davis), had died in an explosion, the images shared by Find The $\mathrm{X}$ indicated that he would be back for the show's new episodes. The scene showing Scully in black clothes and carrying a funeral urn also sparked curiosity on Twitter. The audience tried to find out which character close to the FBI agent could have died. 
However, the sequence that was more widely shared by Twitter users involved the narrative arc of William, the son of Mulder and Scully, who was given up to be adopted as a baby. After analyzing the videos shared by Find The $\mathrm{X}$, the fan discovered a frame in which the character calls his biological parents. This led to further analysis: using screen captures from Fox's transmedia strategy, interacting fandom compared Mulder's and Scully's hands to figure out who had received William's phone call (Figure 3).

\section{Figure 3. Audience members analyze scenes frame by frame on Twitter. A profile of a fan tries to find out who is the recipient of William's phone call}
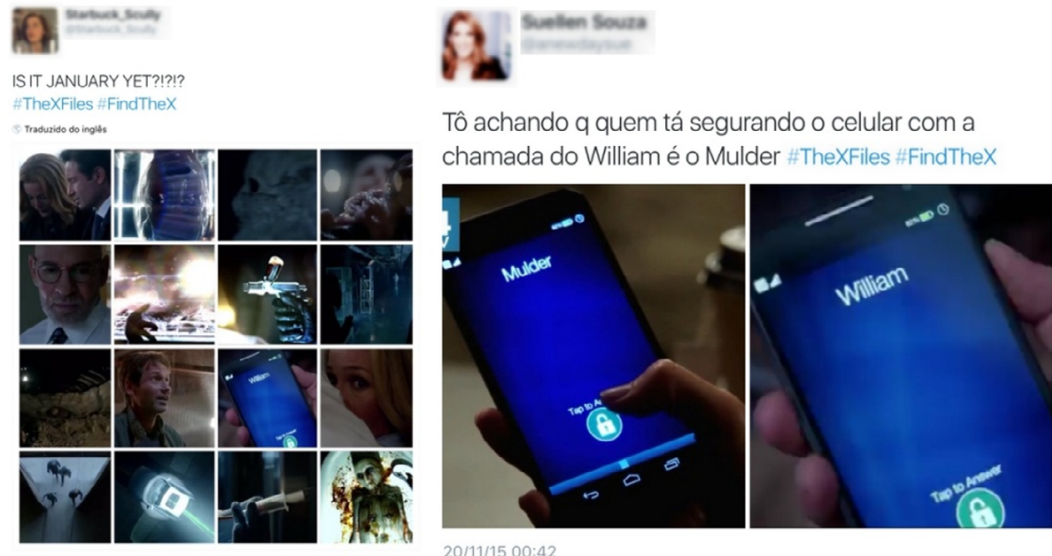

20/11/15 00:42

Source: Twitter.

Tweets posted by the audience in the microblogging platform also highlighted the show's narrative conventions. After sharing frames, the interacting fandom inserted subtitles in the characters' dialogues and connected the scenes to narrative arcs of episodes aired from 1993 to 2002. This was done, for example, with lines spoken by Scully in episodes "Beyond the Sea"12 and "Home Again"13 from seasons one and ten, respectively. In both episodes, the FBI agent criticizes Mulder's subjective involvement with the investigations, but states that, in spite of their disagreements, she will support him. Other elements analyzed by viewers were fantasy sequences. Some

12 The thirteenth episode of season one first aired on January 7, 1994.

13 The fourth episode of season ten first aired on February 8, 2016. 
tweets pointed out aspects such as lighting, angles, costuming and the cast's appearance to identify which scenes were actually part of the plot's fictional universe and which were only characters' imagination.

After analyzing every detail of content shared by Find The X, the audience organized the images in a logical order (Figure 4). Since they were short videos, no longer than a few seconds, the scenes didn't present a linear narrative.

\section{Figure 4. A profile attempts to establish a logical sequence for the scenes shared by The X-Files's transmedia action}

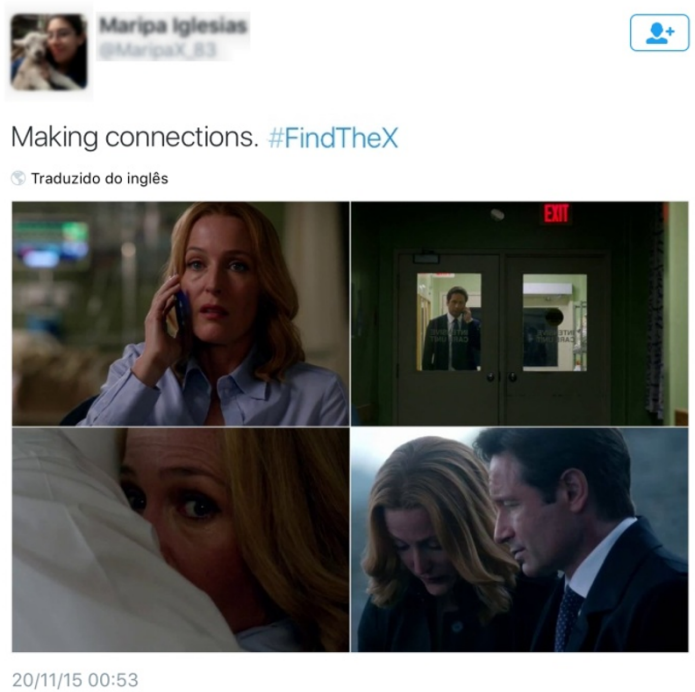

Source: Twitter.

In this manner, the interacting viewers attempted to establish a chronological order for the season's events, based on each frame. The connections established by tweets were guided by elements such as character reaction, narrative arcs, costumes, and photography.

The transmedia action developed by American network Fox for the tenth season of The X-Files promotes creation, analysis and correlation between different contexts and media platforms. Thus, as indicated by Jenkins (2013), transmedia literacy encourages learning through participation, 
collaboration and critical understanding of the fictional universe of serialized fictional narratives.

\section{Final Thoughts}

Find The $\mathrm{X}$ clearly consolidates the main points of transmedia literacy. In every step, The X-Files's transmedia action demands audience multilateralism to establish complex and polysemic interconnections between the show's contents. The strategy also encourages the interacting viewers' creative production on Twitter, through posts in which the audience deepens and re-signifies the attraction.

The release of season ten videos was essentially dependent on audience participation, not only to replicate and reach the number of retweets determined by Fox, but to solve the tweets' riddles. The clues distanced themselves from the story's central narrative arcs, referencing details of the characters' trajectories. After finding out the answer, the audience had to access a specific Twitter profile and RT until reaching the goal established by the network. Afterwards, the audience had to visit blogging platform Tumblr, type out a password, redirect to YouTube and watch closely the exclusive scenes, shown in just a few seconds.

After the content's release, the audience broke down each video into hundreds of frames. The tweets posted with the action's official indexing, hashtag \#Find TheX, established an interconnection between seasons aired from 1993 to 2002 and new episodes. Therefore, every aspect of the scenes was systematically discussed and analyzed in the microblogging platform. The interacting audience's creative production helped to enhance Chris Carter's fictional universe and to expand the plots that were part of Find The $X$.

However, it's worth considering to what extent the work made by fans can be appropriated by networks. When releasing transmedia actions and inviting the audience to solve riddles and replicate content surrounding the fictional universe, networks have their products instantly shared on social media. Discussions around the plot's expansion contribute, even if indirectly, to the show's popularity. 
Despite being a recent concept, transmedia literacy dialogues not only with the possibilities for engagement in a convergence environment, but particularly with the dense and complex fictional universes of contemporary serialized fictional narratives. In this context, transmedia literacy promotes the audience's creative production and the tweets broaden, deepen and re-signify the plot.

\section{References}

Borges, G., Brandão, M., Sigiliano, D., Vieria, S., \& Fernandes, G. (2017). Fãs de Liberdade, Liberdade: curadoria e remixagem na social $\mathrm{TV}$. In M. I. Vassallo de Lopes (Ed.), Por uma teoria de fãs da ficção televisiva brasileira II: práticas de fãs no ambiente da cultura participativa (pp. 93-135). Porto Alegre, Brazil: Sulina.

Borges, G., \& Sigiliano, D. (2016). Television dialogues in Brazilian fiction: Between production and consumption. Applied Technologies and Innovations, 12(2), 54-68. DOI: 10.15208/ati.2016.05

Carter, C. (Executive Producer). (1993). The X-Files [TV show]. Los Angeles, CA: Fox.

Ciastellardi, M., \& Di Rosario, G. (2015). Transmedia literacy: A premise. International Journal of Transmedia Literacy, 1, 7-16. DOI: 10.7358/ijtl-2015-001-cias

Clerc, S. J. (1996). DDEB, GATB, MPPB and Ratboy - The X-Files media fandom online and off. In D. Lavery, A. Hague, \& M. Cartwright (Eds.), Deny all knowledge-Reading the X-Files (pp. 36-51). New York, NY: Syracuse University Press.

Dinehart, S. (2008, May 14). Transmedial play: Cognitive and cross-platform narrative [Blog entry]. Retrieved from http://narrativedesign. org/2008/05/transmedial-play-cognitive-and-cross-platform-narrative/ 
Dowd, T., Niederman, M., Fry, M., \& Steiff, J. (2013) Storytelling across worlds: Transmedia for creatives and producers. London, UK: Taylor \& Francis Group.

Evans, E. (2011). Transmedia television: Audiences, new media and daily life. New York, NY: Routledge.

Fechine, Y. (2016). TV Social, práticas interacionais e modos de presença: contribuição para a delimitação do conceito. XXV Encontro Anual da Compós, (1), 1-14. Retrieved from http://www.compos.org. br/biblioteca/pdfformatsite_3428.pdf

Figueredo, V. L. F. (2010). Narrativas migrantes: literatura, roteiro e cinema. Rio de Janeiro, Brazil: PUC-Rio/7Letras.

Freeman, M. (2017). Historicising transmedia storytelling-early twentieth-century transmedia story worlds. New York, NY: Routledge.

Herr-Stephenson, B., Alper, M., \& Reilly, E. (2013). T is for transmedia: Learning through transmedia play. Retrieved from https://joanganzcooneycenter.org/wp-content/uploads/2013/03/t_is_for_ transmedia.pdf

Jenkins, H. (2006). Convergence culture: Where old and new media collide. New York, NY: New York University Press.

Jenkins, H. (March 8, 2013). T is for Transmedia.... Confessions of an acafan [Blog entry]. Retrieved from http://henryjenkins.org/ blog/2013/03/t-is-for-transmedia.html

Jenkins, H., Green, J., \& Ford, S. (2012). Spreadable media: Creating value and meaning in a networked culture. New York, NY: New York University Press.

Johnson, S. (2012). Tudo que é ruim é bom para você:como os games e a TV nos tornam mais inteligentes. Rio de Janeiro, Brazil: Zahar. 
Jost, F. (2011). Novos comportamentos para antigas mídias ou antigos comportamentos para novas mídias? Revista Matrizes, 4(2), 93-109. DOI: 10.11606/issn.1982-8160.v4i2p93-109

Kinder, M. (1991). Playing with power in movies, television, and video games: From Muppet Babies to Teenage Mutant Ninja Turtles. Berkeley, CA: University of California Press.

Levy, P. (2014). A inteligência coletiva-Por uma antropologia do ciberespaço. São Paulo, Brazil: Loyola.

Livingstone, S. (2004). What is media literacy? Intermedia, 32(3), 18-20. Retrieved from http://eprints.lse.ac.uk/id/eprint/1027

Lotz, A. (2007). The television will be revolutionized. New York, NY: New York University Press.

Mclean, A. L. (1998) Media effects: Marshall McLuhan, television culture, and “The X-Files”. Film Quarterly, 4(51), 2-11. Retrieved from http: / / www.iyfipgun.com/?dn=www.ravenndragon. net $\% 26$ pid=9POL6F $2 \mathrm{H} 4$

Mittell, J. (2015). Complex TV: The poetics of contemporary television storytelling. New York, NY: New York University Press.

Pearson, R. (2010). Fandom in the digital era. Popular Communication: The International Journal of Media and Culture, 1(8), 84-95. DOI: $10.1080 / 15405700903502346$

Potter,J. (2010). The state of media literacy. Journal of Broadcasting \& Electronic Media, 54(4), 675-696. DOI: 10.1080/08838151.2011.521462

Reeves, J. L., Rodgers, M. C., \& Epstein, M. (1996). Rewriting popularity-The cult files. In D. Lavery, A. Hague, \& M. Cartwright (Eds.), Deny all knowledge-Reading the X-Files (pp. 22-35). New York, NY: Syracuse University Press. 
Rosenbaum, J. E., Beentjes, J. W. J., \& Konig, R. P. (2016). Mapping media literacy: Key concepts and future directions. Journal Annals of the International Communication Association, 32, 313-353. DOI: 10.1080/23808985.2008.11679081

Scoladari, C., \& Felder, J. L. (2000). Creating a pocket universe: "Shippers," fan fiction, and the X-Files online. Journal Communication Studies, 3(51), 238-257. DOI: 10.1080/10510970009388522

Scolari, C. A. (2016). Transmedia literacy: Informal learning strategies and media skills in the new ecology of communication. Revista Telos - Cuadernos de Comunicación e Innovación, (103), 1-9. Retrieved from http://hdl.handle.net/10230/27788

Sigiliano, D., \& Borges, G. (2016). O diálogo entre a complexidade narrativa e a social $T V$ no projeto XFRewatch da série The X-Files. En XXV Encontro Anual da Compós, 1, 1-16. Retrieved from http:// www.compos.org.br/biblioteca/odi\%C3\%81logoentreacomplexidadenarrativaeasocialtvnoprojetoxfrewatchdas\%C3\%89riethex-files_3392.pdf

Sigiliano, D., \& Borges, G. (2017). The X-Files: uma análise das estratégias de social TV do perfil @thexfiles. Comunicação, Mídia e Consumo, 13(39), 1-22. DOI: 10.18568/cmc.v14i40.1378

The X-Files. (2015a, November 19). Want to play \#FindTheX? We've created an online scavenger hunt with a Flock to Unlock. Get ready for our next tweet...\#TheXFiles [Tweet]. Retrieved from https://twitter. com/thexfiles/status/667386113938628608

The X-Files. (2015b, November 19). On \#TheXFiles she is sometimes called Starbuck...she has hidden the X. Find it \& RT w/ \#FindTheX. $10 \mathrm{~K}$ tweets unlocks a glimpse of the truth! [Tweet]. Retrieved from https://twitter.com/thexfiles/status/667403880292945920 
Universal Cable Productions LLC. (2016). Mr. Robot:1.51exfiltratiOn.ipa [Video game].Retrieved from https://itunes.apple.com/us/app/ mr-robot-1-51 exfiltrati0n-ipa/id1138484918?mt=8

Willians, L. R. (2005). Twin Peaks: David Lynch and the serial-thriller soap. In M. Hammond \& L. Mazdon (Eds.). The contemporary television series (pp. 28-61). Edinburgh, Scotland: Edinburgh University Press. 